\title{
The value of quality
}

\author{
András Nábrádi \\ Faculty of Agricultural Economics and Rural Development, \\ Department of Business Economics and Marketing, \\ Centre of Agricultural Sciences and Engineering, University of Debrecen
}

\begin{abstract}
The significance of quality production and quality improvement is widely acknowledged by many but few specify what should be improved and what quality should be produced.

The reason may be that there are different quality categories in the process of the value chain. Moreover, the issue of quality costs, i.e. economically optimal quality has not yet been explored yet. The present study raises problems in the pigmeat verticum, but similar studies are needed in other animal husbandry sectors as well. It is reasonable to treat the quality categories of animal products in a complex way, as this allows the full satisfaction of consumer expectations at the certain stages of the value chain and solvent demand as well.
\end{abstract}

Keywords: Quality, quality costs, quality categories, economically optimal quality, value chain, animal husbandry

\section{Introduction}

The significance of quality production and quality improvement is widely acknowledged by many but few specify what should be improved and what quality should be produced. The reason for this is the fact that the issue is more complicated than it seems.

\section{What is meant by quality?}

Before getting directly to the point, the notion of quality should be clarified. The person who starts dealing with this issue faces immediately the fact that the notion of quality has got several definitions. Philip B. Crosby $(I 1,1996)$ claims that quality "means the satisfaction of needs and not elegance". The definition expresses the essence of quality, i.e. that the full scope of customer expectations is to be taken into consideration while corporations strive to direct their organizations to fulfil these expectations. Taguchi et al. (2004) define the notion of quality as a loss caused to society which they present on a quadratic loss-function. According to certain experts, the use of this definition is highly restricted by the negative attribution attached to the notion. Taguchi claims that the better the quality of the product, the lower the loss caused to society - including buyers and producers - will become.

David Garvin (1988) states that "quality is pleasuring customers, not merely the prevention of annoyance". Shiba et al. (1993) define four levels of quality. The first is compliance with standards and specifications; the second is the satisfaction of well-known consumer needs; the third is appropriate price/cost relation as a regulating factor; and the fourth is when organizations target users' latent, unspoken demands. Joseph M. Juran (1951, 1999), one of the mostly renowned experts of quality in the U.S.A., focuses on consumers in his approach, claiming that "quality is compliance with consumer needs". This essentially equals with the wording of the ISO8402: Technical Dictionary of Quality Control and Quality Insurance, i.e. "the sum of those characteristics which influence capacities in satisfying determined and expected needs". According to ISO 9000:2001: "quality is the rate of the extent to what a group of own characteristics can fulfil requirements. The definitions of ISO 9000:1996 suggest that "quality is the sum of the characteristics of a unit which influence its capacities in satisfying determined and expected needs." The notion of quality varies today as well, as it is markedly illustrated in its wording: "quality is the sum of those features or characteristics of products or services which influence the capacities of products or services in satisfying expressed or expectable needs" Nowadays the strategic definition has come into the limelight: "Quality is a basic business strategy by the help of which products and services fully satisfy both internal and external buyers, meeting their spoken and unspoken expectations", i.e. briefly: quality equals with meeting customers' demands.

\section{What can be taken into consideration when pigmeat quality is evaluated?}

In the relation of pigmeat and pork products the above mentioned definitions have enriched our knowledge; however, they have not disclosed the notion of quality products. Qualification after slaughter is a tangible fact. The qualification of pork carcasses after EU conform slaughter was developed and introduced in the eastern European 
countries in the early 90 's, which means the percentage of lean meat from carcasses. Qualification can be performed by instruments or by measurements at the splitting level of carcasses (2-point method). Measurements are taken with perforation-probe equipment and data processing is computerized. The letters SEUROP mean six quality categories according to lean meat production:

Table 1: Qualification of pork after slaughter and its value in Hungary and Denmark

\begin{tabular}{|c|c|c|c|}
\hline Quality categories & Lean meat\% & Hungary & Denmark \\
\hline $\mathrm{S}$ & over 60.0 & 6.33 & 53.30 \\
\hline $\mathrm{E}$ & $55.0-59.9$ & 46.50 & 42.20 \\
\hline $\mathrm{U}$ & $50.0-54.9$ & 35.05 & 4.30 \\
\hline $\mathrm{R}$ & $45.0-49.9$ & 9.93 & 0.20 \\
\hline $\mathrm{O}$ & $40.0-44.9$ & 1.77 & 0.00 \\
\hline $\mathrm{P}$ & below 40.0 & 0.41 & 0.00 \\
\hline
\end{tabular}

Source: Bíró-Ozsvári 2006

Under the regulations, processors and slaughterhouses are obliged to notify producers on the results of qualifications. On the basis of quality information and market demands, pig farmers can get closer to consumer needs.

\section{Can quality be merely characterized with these parameters?}

The question emerges whether the cluster of the parameter described in Table 1. is enough for the evaluation of good pig product? Probably not! Further criteria for the quality requirements of products can be generally worded as well: achieved quality should be equable and reliable, the same product should always be the same, and also they should be durable, aesthetic and so on. The situation is further complicated by the fact that producers, processors and distributors mean the notion of quality differently, just like end users, i.e. consumers. Table 2. presents the certain quality expectations in the process of the value chain.

Table 2. represents that producers, processors and distributors have completely different judgements and expectations - though processors base them on producers' value judgement - and by the time a product is on the consumer's table, in kitchens, restaurants or on department store shelves, producers' quality expectations will have modified, the aspects of their value judgement will have multiplied. Although the main motivators for producers are specific productivity, mass growth, resistance, reliability and saleability, i.e. marketability, by the time the products gets on the table, losses on processing, the time for kitchen preparation, amenity value, the general impression of the product, taste, colour, odour and tenderness will have become priorities. Today the issues of health protection, healthy diet and functional foods are in the focus of attention and packaging is also a vital factor. However, the list of quality expectations is not complete: food safety and hygiene are essential factors in the whole process of the value chain. Food safety guarantees consumers' safety against harmful components included in foodstuff, food hygiene is for the prevention of contamination and other harmful effects in foods (J. Szabó 2006). A special feature of quality is the fact that it should not only comply with consumers' value judgement, but with the principles of use and usefulness as well. The latter ones have become especially significant for the last decade in meeting ecological (bio, natural and nature friendly) and psychological expectations, preconceptions and images. Last but not least I mention the economic value of quality.

The above mentioned suggest that there is no and there cannot be a single definition of quality for the judgement of animal products. To my understanding, the key "quality controller" is the consumer, i.e. products should comply with consumers' conceived and spoken expectations. If quality is weighed from the viewpoint of social usefulness, this can probably divert consumers' value judgement (e.g. nature friendly, health protective or contaminating product). The conclusion is evident: there are several quality categories for the evaluation of animal products. Producers, processors, traders and consumers all have different value judgements. Quality expectations are influenced by compliance with food hygiene and food health regulations and also macro-level social usefulness.

In the following part we present an overview on the expenses and costs that can influence certain levels of expectations.
Table 2: Aspects of quality evaluation in the value chain

\begin{tabular}{|l|l|l|l|}
\hline Producer & Processor & Distributor & Consumer \\
\hline Specific producing & Processibility & Transport & Rate of processibility \\
capacity & Physical & characteristics & Loss on processing \\
Weight gain & characteristics & Storage life & Time needed for kitchen-preparation \\
Resistance & Uniformity & Packaging & Uniformity, stability \\
Reliability & Shelf-life & Labelling & Taste, odour, colour and tenderness \\
Animal's useful & Capacity & Brand name & General impression, amenity value \\
lifetime & indicators & Marketability & Origin of product \\
Storage life and & Brand name & & Species/type, age, sex \\
transportability of & Marketability & & Health protection (level and rate of \\
product & & & unsaturated fatty acid, functionality) \\
Marketability & & & Packaging, labelling \\
\hline
\end{tabular}

Source: author's own compilation

\section{Quality costs}

It is well-know that the process in which a product gets from a lower to a higher quality level acknowledged by the market, takes additional input. However, only few consider that if a product does not reach a required minimum level, this also means additional input. What does additional input mean? Some take into consideration merely input resulting in a higher use vale, whereas efforts to 
inspire confidence in a product of satisfactory quality also generate costs. When quality and costs are mentioned, stock breeders almost all neglect that fact that a loss generated when a product of unsatisfactory quality is produced becomes a cost (destruction of returned goods, production costs of useless or undervalued goods).

The definition of quality cost highlights this fact: under ISO 8402: quality costs are those costs which are generated when satisfactory quality is provided and related confidence is inspired and all those losses which occur when satisfactory quality is not reached. What is the volume of quality cost? National and international technical literature claims that concrete calculations have not yet been performed in animal husbandry and in the pig sector either.

Theoretical approaches and calculations discussing its order of magnitude can be found in several studies. I will base the presentation of the elements of relevant quality costs in the pig sector on them.

First of all, in the following I will focus on the categories of quality for producers, and I will not discuss the quality costs of processors, distributors and users.

\section{Quality costs in animal husbandry sectors}

The above mentioned related technical literature distributes quality costs into four categories: prevention of quality defects, quality insurance-maintenance and costs due to internal and external defects. In the case of animal husbandry these four categories can be supplemented with a specific factor, namely with expenses related to biological bases (more precious breed, hybrid).

\section{Why is it problematic to take quality costs into consideration?}

In a classical sense, the classification of quality cost can be problematic for economic experts who would like to see and analyze these factors clearly. The reason is that accounting records are not always "quality cost friendly". The expenses which are directly or indirectly emerge should be collected separately in the accounting system.

When costs are reckoned, contradictions may arise when the quality related operations of various units and organizations are to be considered simultaneously.

Certain organizations perform other types of (not quality insurance) activities and certain quality insurance activities use various resources (materials, wages, instruments etc.). Therefore we may not see concrete examples in agriculture and especially in animal husbandry. Table 3. shows the groups of quality costs according to the accounting system, providing a clearer picture in this issue. Before presenting this in detail, let us examine the following basic question from the viewpoint of producers:

\section{To what extent should quality be increased?}

The answer is simple, although the concrete answer presupposes the comprehensive consideration of several factors. Quality is worth increasing until it reaches the economically most favourable i.e. optimal rate. It can be calculated with the following formula:

$$
O M=\frac{\sum_{i=1}^{n} M B}{\sum_{J=1}^{n} M K} \Rightarrow \max .
$$

Where: $O M=$ economically optimal quality

$\Sigma M B=$ Extra return from sales due to higher quality

$\Sigma M K=$ Costs of additional input generating higher quality (quality cost)

To put it into words: optimal economic quality is the level of expenses in terms of money, increasing quality, where surplus revenue, by reaching a higher level of quality and the quotient of resources used to reach this higher level, is the highest (take a maximum value).

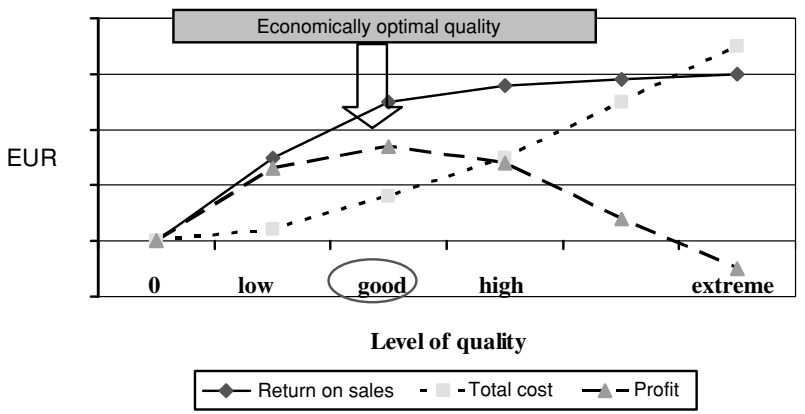

Figure 1. Economically optimal quality

The formula in figure 1. presents the correlation graphically. What does this correlation suggest? Naturally the fact that for the definition of economically optimal quality we have to get a good understanding of expenses that generate higher quality, its costs and at the same time extra return from sales due to higher quality. The level of quality is worth increasing as long as profit grows. The curve of the figure suggests two primary conditions. First, to reach higher quality costs more and increasingly more as compared to the previous level of quality; second, the process of reaching a higher quality is progressive, i.e. the growth of the return from sales follows the principle of diminishing returns. However, these two assumptions have not yet been proved, merely presupposed. To prove them, the variations of expenses and returns from sales have to be examined on the different levels of quality.

The following part presents which factors influence quality costs and to what extent.

\section{Quality in practice}

\section{Quality for producers}

In the analysis of quality for producers we investigate how producers can reach and increase required quality and how much it costs for them. 
Generally it can be mentioned that from producers' side quality animal products can be influenced by using better quality breeding animals, better foraging satisfying animal needs, by providing higher level keeping technologies and technical conditions and human factors adjusted to all these issues. Let us examine the expense needs of all these factors, based on some categories of the accounting records.

\section{Material costs}

The classification of the types of costs (Table 3.) shows that producers can modify quality by using extra input in the case of breeds, hybrids, forages, complementary feedstuffs, health care and prevention, listed among material costs. Producers can decrease their opportunity costs if they do not have to pay for the input due to quality defects listed among the material costs of the table.

Genes carrying the parameters of efficiency in new types and hybrids usually take extra expenses. As its tangible result, the price of higher quality breeding animals and the sum to be paid for their sperms in the case of artificial insemination may be significantly higher as compared to lower quality sperms. In the event of breeding boars, the price difference can be the order of 100 thousand HUF. What are the results of this difference in prices? Naturally, knowing that not only genetic bases determine several parameters, we can assume that the number of weaned pigs (23.2 in Denmark, 18.26 in Hungary), the production of fattening pigs per sows (21.5 in Denmark, 17.7 in Hungary) weight gain in the fattening period $(804$ gr/day in Denmark, $584 \mathrm{gr} /$ day in Hungary) will grow (Bíró-Ózsvári 2006, Windhorst 2003).

The prices of forages, feeds and complementary feedstuff may vary extremely. Producers decide what the most appropriate variations are which suit breeds/hybrids, genders and age groups. Forages, feeds and complementary feedstuff which meet animal demands the best are usually more expensive than similar ones replacing them. Foraging can influence the ratio and the volume of meat-fat, the composition of fat content, the percentage of vitamins and

Table 3: Production costs of quality animal products

\begin{tabular}{|c|c|}
\hline TYPE OF COST & name \\
\hline 1. Material costs & $\begin{array}{l}\text { 1. Valuable biological basis (type, hybrid, sperm) } \\
\text { 2. Better forages and better complementary feedingstuff } \\
\text { 3. Preventive materials and feeds for animal health } \\
\text { 4. Better quality drinking water } \\
\text { 5. Material costs of examinations on durability and reliability } \\
\text { 6. Extra material costs for faulty products of unacceptable quality under guarantee } \\
\text { 7. Extra expenses due to products returned by customers for quality problems; costs of scrapping } \\
\text { 8. Emergency slaughter of young and fattening animals which have failed to reach the required quality or costs of } \\
\text { technological culling }\end{array}$ \\
\hline 2. Wages and salaries & $\begin{array}{l}\text { 1. Labour costs of time periods for ISO, TQM, etc. meetings of governing bodies } \\
\text { 2. Labour costs of time periods for the development of handbooks and procedural instructions } \\
\text { 3. Labour costs of time periods for improvements and audits } \\
\text { 4. Labour costs of time for personnel in relation to the planning and development of quality insurance systems } \\
\text { 5. Labour costs of the information system of quality } \\
\text { 6. Internal audit is the maintenance cost for the operation of the quality insurance system } \\
\text { 7. Internal labour costs of examinations on durability and reliability } \\
\text { 8. Supervision of the quality of transported goods, labour costs and dues of quality supervisors } \\
\text { 9. Labour costs of provision during the manufacture of products or included in the processes of production } \\
\text { 10. Costs of final supervision, the labour cost of internal supervision }\end{array}$ \\
\hline $\begin{array}{l}\text { 3. Depreciation allowance } \\
\text { for specific tangible assets }\end{array}$ & $\begin{array}{l}\text { 1. Depreciation costs for the tangible assets of quality information systems } \\
\text { 2. Amortization of testing equipment for the examination of the quality of delivered goods } \\
\text { 3. Depreciation of technological tangible assets purchased to improve or maintain higher quality } \\
\text { 4. Depreciation of lower quality, out of use but unsold tangible assets (cost remanency) } \\
\text { 5. Costs of emergency or technological culling for breeding animals of inadequate quality } \\
\text { 1. R+D costs of measurement } \\
\text { 2. Penalty pay for defect of quality and testing equipment }\end{array}$ \\
\hline $\begin{array}{l}\text { 5. Divided costs (services in } \\
\text { ancillary sectors }+ \text { others) }\end{array}$ & $\begin{array}{l}\text { 1. Internal service costs of technological equipment purchased to increase quality } \\
\text { 2. Consultancy costs } \\
\text { 3. Costs of quality training performed by external servicers } \\
\text { 4. Supervision costs for the operation of the quality insurance system, costs of supervisory audit and re-qualification } \\
\text { 5. Costs of external services, durability and reliability tests } \\
\text { 6. Service costs of courses and conferences } \\
\text { 7. Costs of qualification tests, e.g. costs of OMMI qualification prior to the introduction of a new product or breed } \\
\text { 8. Costs of qualifying suppliers and sub-contractors }\end{array}$ \\
\hline 6. Sales costs & $\begin{array}{l}\text { 1. Marketing costs to increase the reputation and marketability of higher quality products } \\
\text { 2. Delivery costs of defective, unacceptable quality products }\end{array}$ \\
\hline 7. Administrative costs & 1. Administrative costs of the quality information system \\
\hline $\begin{array}{l}\text { 8. Expenditure of financial } \\
\text { transactions }\end{array}$ & 1. Interest charges of credits taken out to increase quality \\
\hline
\end{tabular}


Table 4: Some cost items in the \% of total production costs in Hungary

\begin{tabular}{|l|c|c|c|c|c|c|}
\hline Name & $\begin{array}{c}\text { Milk } \\
\text { production }\end{array}$ & $\begin{array}{c}\text { Fattening } \\
\text { of pigs }\end{array}$ & $\begin{array}{c}\text { Rearing } \\
\text { sows }\end{array}$ & $\begin{array}{c}\text { Fattening } \\
\text { of chickens production }\end{array}$ & $\begin{array}{c}\text { Egg } \\
\text { breeding }\end{array}$ \\
\hline Depreciation of breeding animals & $5-8$ & - & $3.0-6.5$ & - & $3.6-18.0$ & $4.4--9.7$ \\
\hline Costs of feedstuff & $48-63$ & $42-53$ & $51-61$ & $53-64$ & $48-63$ & $58-60$ \\
\hline Costs of animal health & $2.4-3.5$ & $1.2-1.7$ & $3.2-4.0$ & $1.6-2.8$ & $0.2-0.5$ & $3.9-4.2$ \\
\hline Natural and artificial insemination & $1.4-2.3$ & - & $0.3-1.5$ & - & - & $.02-0.2$ \\
\hline Depreciation & $2.5-4.3$ & $1.7-2.8$ & $2.1-2.8$ & $2.0-2.8$ & $1.1-5.9$ & $1.5-5.6$ \\
\hline
\end{tabular}

Source: on the basis of data (2004-2005) from AKI and the author's own calculation

indices should not be overestimated! A study in 2003 suggests that in Canada, compared to the most developed pig breeding nations in Europe, the availability of forages was the worst in the fattening period (3.39 $\mathrm{kg} / \mathrm{kg}$ ), in contrast with e.g. Denmark, where it was $2.7 \mathrm{~kg} / \mathrm{kg}$. Nevertheless, the cost of feedstuff per $1 \mathrm{~kg}$ of carcass was 0.61 û in contrast with the Danish value of $0.65 €$. The ratio was

minerals, taste and colour, bio-quality and food safety (Gundel 2006). The quality parameters of pig SEUROP, which are manifested in delivery price, incite producers only partially to improve in the areas discussed by Gundel and to realize surplus investment. Producers actually measure their specific forage use. This significant index shows a high standard deviation 4.57 in Hungary $(3.41-7.92 \mathrm{~kg} / \mathrm{kg}$ ) on average, while in the Netherlands it hardly exceeds 2.6 $\mathrm{kg} / \mathrm{kg}$, and it is $2.7 \mathrm{~kg} / \mathrm{kg}$ in Denmark (Bíró-Ózsvári 2006, H.W. Windhorst 2003).

The issue of foraging is highly significant as during the manufacture of animal products, feedstuff itself amounts to the major part of total expenditure. Table 4. shows the significant cost items in the key sectors of animal husbandry.

Table 4. shows that foraging costs amount to $42-61 \%$ of total costs in pig breeding. How does it correlate with economically optimal quality? The answer is self-evident. Foraging technologies are to be applied where the same input yields higher proceeds or extra input is to be used which increases economic results (return on sales through yield) to a greater extent than the value of input in terms of money. A key correlation is to be mentioned here. The availability of forages and daily body mass growth are the primary natural indices of the efficiency of foraging. However, natural

Table 5: Deterioration of forage availability (\%), decreasing body mass growth (\%) and mortality rate in the event of the outbreak of diseases

\begin{tabular}{|c|c|c|c|}
\hline Illness & $\begin{array}{c}\text { Decline } \\
\text { in forage } \\
\text { availability } \%\end{array}$ & $\begin{array}{c}\text { Acute form } \\
\text { Decline in daily } \\
\text { body mass growth\% }\end{array}$ & Mortality rate \\
\hline Disease caused by E. Coli & 3 & $3-5$ & Pigs $1 \%$ \\
\hline Aujeszky's disease & $3-6$ & $3-10$ & $\begin{array}{l}\text { Pigs } 25-35 \text {, fattening } \\
\text { pigs } \quad 4-8 \%\end{array}$ \\
\hline $\begin{array}{l}\text { Pneumonia caused by } \\
\text { Micoplasm }\end{array}$ & $6-12$ & $3-10$ & $\begin{array}{c}\text { Sows } 1-4 \%, \\
\text { post-rearing } 5 \%\end{array}$ \\
\hline $\begin{array}{l}\text { Pneumonia caused by } \\
\text { Actinobacillus }\end{array}$ & $3-12$ & $5-25$ & $\begin{array}{l}\text { Pigs and fattening } \\
\text { pigs: } 2-15 \%\end{array}$ \\
\hline Atrophic rhinitis & $3-6$ & $3-10$ & $\begin{array}{c}\text { Increases by } 1-5 \% \text { after } \\
\text { weaning }\end{array}$ \\
\hline Pig dysentry & $6-15$ & $10-15$ & $\begin{array}{c}\text { Increases by } 1-4 \% \text { after } \\
\text { weaning }\end{array}$ \\
\hline Steptococcosis & 1.5 & $0.75-3$ & $\begin{array}{c}\text { Increases by } 4-12 \% \text { after } \\
\text { weaning }\end{array}$ \\
\hline Mange & $3-9$ & $5-13$ & \\
\hline Internal parasites & 3 & $5-13$ & \\
\hline
\end{tabular}

Source: Bíró-Ózsvári (2006) similar in the case of the U.S.A. and the Netherlands. The reason is that although specific availability was lower overseas, the prices of maize and soy were much lower (Windhorst 2003). In spite of this fact, the availability of feedstuff and daily mass growth are to be highlighted. Supposing that more expensive feedstuff results in higher mass growth and better availability as well, we may consider extra expenses. Supposing that all other financial factors are unchanged, under average conditions feedstuff is more expensive by $40 €$ - increasing production costs by $0,12-0,16 € / \mathrm{kg}$. Literary data suggest the variation of the two indices in the event of various diseases (Table 5.).

The significance of data in Table 5. can only be appreciated if we consider not only increasing forage costs (the fall of forage availability is in direct proportion with the rise of forage costs), but the additional extra expenses which are related to decreasing body mass growth and mortality as well. What does it mean? The direct result of decreased body mass is the extension of fattening time. Simultaneously, all the cost items increase (material costs including energy, forage, drinking water, labour costs and wages, service costs etc.). Changes in the mortality rate of animals are three times detrimental! First, used forages, energy, labour costs etc. are lost; second, dead animals do not generate return on sales; third, the destruction costs of carcases fall upon the sector as well. For the good understanding of the issue an another significant fact is to be considered. Table 4. presents that animal health costs amount to merely $1-4 \%$ of all production costs in the pig sector. It is to be considered: what is worth more? Prevention, higher life performance by having a healthier livestock or the expenses of treatments, extra costs due to diseases or losses.

Quality costs are basically determined by two categories. First, quality costs are those costs which are needed for the realization of the required quality and those ones which occur when the required quality is not reached. Practical experience suggests that total quality costs can be decreased if prevention activities are enhanced and related expenditure is 
raised. Economically optimal quality for animal breeders (producers) can be characterized by two parameters. Producers should produce the given quality slaughter animals (e.g. E quality) at the lowest possible production costs. It may be far away from consumers' quality expectations (tenderness, savouriness, taste, flavour, processibility), but producers do not care about it.

The reason is that expected quality for producers is the standard or the contracted requirement. Producers primarily aim to manufacture the given quality at the lowest possible cost. Reversing the same correlation, quality for producers means products at the lowest possible production cost as compared to takeover (buying-in) price As producers fail to receive extra profit if functional food is prepared from their products or these contain the appropriate level of Omega 3 fatty acids, producers do not care if their meat products shrink during roasting. Producers are merely interested in their profits!

\section{Some further elements of quality cost}

Table 4. also highlights that depreciation in the pig sector does not amount to $3 \%$ of total costs. However, this relatively "cheap" factor is the basis of technological development and conditions better suiting animal needs.

The results of a real development underpin the above mentioned statement: analyzing the parameters of pig fattening, an enterprise set itself the target to increase mass growth by $100 \mathrm{gr} /$ day, the indices of specific forage availability on local units by $0.5 \mathrm{~kg} / \mathrm{kg}$, decrease its technological spoilage (losses) from 20\% to lower than 5\%, increase its sold mass from $95 \mathrm{~kg}$ to $105 \mathrm{~kg}$, and to decrease the cost of medicine used in animal health simultaneously.

To realize the set objectives, the enterprise considered several solutions. Finally it decided to improve genetic basis of its livestock by purchasing quality breeding soars, to restructure its foraging technologies by the introduction of a new system. Technological restructuring required the reconstruction of buildings, the adjustment of manuring technologies and the modernization of ventilation technologies as well. Besides reconstruction and development, the enterprise decided on the introduction of the quality insurance system as well. The whole development included the following costs: material costs related to genetic bases and quality insurance, labour costs and wages, internal and external service costs, absorbed depreciation and interest charged for its investment loan. The development costs and production costs of the enterprise prior to investmentdevelopment $(0,88 € / \mathrm{kg})$, which is increased - not calculating the impact of innovation - by 4,15 eurocent $/ \mathrm{kg}$.

Now the question is, whether the realization of the set objectives, thus the planned increase of the return on sales will be enough to cover expenses? If the enterprise successfully decreases forage availability by $0.5 \mathrm{~kg} / \mathrm{kg}$ from among the set objectives, the production cost of its products will be lower by 4,8-6,0 eurocent $/ \mathrm{kg}$. This amount not only covers but exceeds the growth of production costs! This simple example highlights that development, the improvement of "quality" parameters would not increase but rather decrease production costs for producers as well! If we look at the correlation of Table 3. again, we can clearly see that in the event of the same takeover price, the impact of quality innovation generates profit as well!

\section{Quality in the further stages of product path}

What quality expectations are characteristic of the further players in the product chain? Processors produce products of higher added value from live animals. Producers' quality expectation is that they should be able to produce highly profitable products from source materials, i.e. output indices are the basic quality expectations for producers. Increased output is essential for them in the product family where the profit margin is high.

What can processors do if they have already exhausted this area? They can develop products, create innovations and produce healthier products. Products that they manufacture by using $\mathrm{R}+\mathrm{D}$ and high input which they promote and pass on to distributors.

To increase quality, this issue should be studied even more carefully. It has already been declared that producers are not or just slightly interested in producing quality for customers. Processors are key players, as they have to meet domestic and foreign market expectations at the same time. The improvement of quality production is primarily controlled by processors. Figure 2. represents the key methods to be applied for the improvement of quality, dividing them into methods used by producers, processors and traders. The figure suggests that compliance with regulations is an expectation in all the three cases, just like

Figure 2. Quality development in the process of the value chain

\begin{tabular}{|c|c|c|c|}
\hline Criterion/methods & Producer & Processor & Distributor \\
\hline Compliance with standard & ++ & +++ & +++ \\
\hline Information on products & + & +++ & +++ \\
\hline $\begin{array}{l}\text { Technological development } \\
\text { technical efficiency, output), }\end{array}$ & +++ & ++ & not typical \\
\hline $\begin{array}{l}\text { Product development } \\
\text { (health, functional food, the } \\
\text { same product with different } \\
\text { characteristics) }\end{array}$ & ++ & +++ & does not exist \\
\hline $\begin{array}{l}\text { Related diversification } \\
\text { product + cook book }\end{array}$ & $\begin{array}{c}\text { does } \\
\text { not exist }\end{array}$ & ++ & +++ \\
\hline $\begin{array}{l}\text { Unrelated diversification } \\
\text { product }+ \text { present }\end{array}$ & $\begin{array}{c}\text { does } \\
\text { not exist }\end{array}$ & + & +++ \\
\hline $\begin{array}{l}\text { Market penetration } \\
\text { (present product, present } \\
\text { market, marketing) }\end{array}$ & $\begin{array}{c}\text { does } \\
\text { not exist }\end{array}$ & ++ & +++ \\
\hline $\begin{array}{l}\text { Market development } \\
\text { (present product, new } \\
\text { market, marketing) }\end{array}$ & + & +++ & +++ \\
\hline Logistics & ++ & +++ & +++ \\
\hline
\end{tabular}

A + expresses the rate of demand for development

Source: author's own compilation 
information related to products. With a simple comparison, quality insurance and food safety are as significant as a licence to drive a car. No products can be placed on markets without them. Technological and product development for the improvement of quality is concentrated in producers' and processors' hands. Responsibility and realization for quality improvement in relation to breeds, hybrids and foraging fall upon producers. Processors can increase expected quality by packaging and converting their products into semi-finished or finished ones. Such improvements are not typical of distributors, if there are any. However, distributors are interested in selling products, so they contribute to product promotion, but as we have already seen, they do not improve them.

Nevertheless, they apply the toolbar widely used in trade. However strange it may sound, this is also included in quality development! Related and unrelated diversification means a kind of discrimination, calling customers' attention to buy the product. Breaking into markets and developing markets include a range of further marketing methods, making products more marketable in the vertical and horizontal system of sales relations.

All the players of the value chain take place in the improvement, development and increase of quality. The required expenses may vary and they actually vary from one another. The present study discusses the issue of quality from the viewpoint of producers, but hopefully it has been revealed that this problem is more complex and cannot be analyzed on some pages in its full profundity.

Future agro-economic research will indispensably need the complex analysis of this issue, rather than the mere analysis of certain elements of the value chain. A complex approach may reveal the truth more successfully, perhaps answering the question what economically optimal quality is. At present this issue is still unclear due to several subjective and objective reasons. Today we do not exactly know what volume costs may occur in the process of the value chain to increase quality. The market structure and cost-related profitability of the whole verticum is extremely disproportionate. This is justified by figure 3. based on price conditions in 2004-2005 in Hungary.

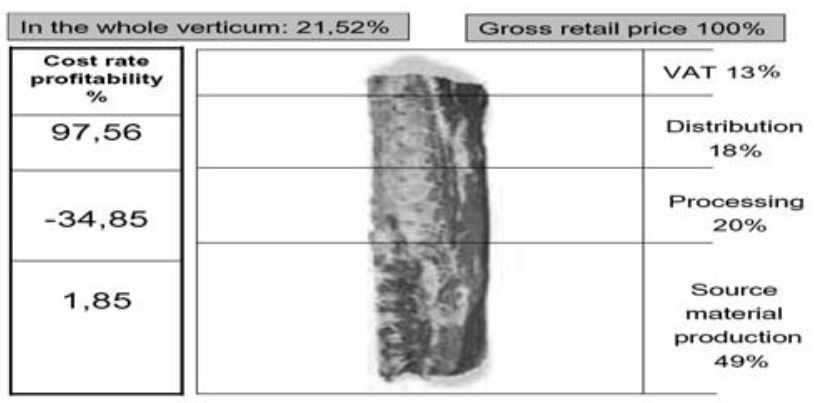

Figure 3. The composition of gross retail price and cost-effective profit for loin in Hungary

Source: Juhász 2005 and the author's own calculations
The figure clearly shows that approximately $50 \%$ of the gross retail price comes from the production of source materials, but cost-rate profitability is only $1.85 \%$. Processors contribute $20 \%$ to the price; however, production is loss-making. Distributors take $18 \%$ from gross retail price, reaching an unbelievably high profitability rate $(97.56 \%)$. This difference, disproportion is an eyesore. To my understanding, the solution of this problem lies in the hands of distributors. If radical changes fail to come, producers are likely to give up their activities processors go bankrupt as a result of their long-lasting losses and there will be nothing to trade with. This might not be in the interest of distributors as in this case there will be no quality products or rather no products for distribution.

\section{List of references}

Bíró O.; Ózsvári L. (2006): Állat-egészségügyi gazdaságtan. SZIE Állatorvos-tudományi Kar, kiadványa, Budapest 70. p.

Crosby, Philip (1996): Quality is still free: Making Quality Certain in Uncertain Times. McGraw-Hill. ISBN 0-07-014532-6.

D. A. Garvin: (1998): Managing Quality. Free Press (February 8, 1988) ISBN-10: 0029113806, ISBN-13: 978-0029113806

G. Taguchi, S. Chowdhury, Y. Wu : (2004): Taguchi's Quality Engineering Handbook, ISBN: 978-0-471-41334-9

Gundel J. (2006): Takarmányozás és életminőség. Állattenyésztés és Takarmányozás. Különszám. Vol. 55. 2006. 5-14. p.

Tibor Varga-Tunyoginé Nechai Veronika-Kemény Gábor (2007): Characteristics of price packages for the more significant domestic farm productions. Gazdálkodás, 51. évf. 6. sz. HU ISSN 0046-5518

H. W. Windhorst (2003): Cost competitiveness of Leading Exporters. Pig Progress, vol. 19. no. 4. 2003. 8-10. p.

I1: http://www.skymark.com/resources/leaders/crosby.asp . 2007:

I2: Quality management systems.Fundamentals and vocabulary ,ISO:9000:2005, ISO 8402,ISO 8402:1994, ISO 9000:2005,ISO 9000:2005.https://www.mszt.hu/mszt/portal/user/anon/page/default.psm 1/js_pane/03; jsessionid=A9643D3EB3479B922A90333A0FDD2FBA? icsid $=03.120 .10$

Juhász A. szerk.; (2005): Piaci erőviszonyok alakulása a belföldi élelmiszerpiac szereplői között. Agrárgazdasági Tanulmányok, AKI, Budapest, 1-141.p. ISBN: 9634914764

Juran, J. M.; Frank M. Gryna (1951): Juran's Quality Control Handbook. Mcgraw-Hill. ISBN 0-07-033176-6.

Juran, J. M.; Godfrey, A.B. K.: (1999): Juran's Quality Handbook (5th Edition) McGraw-Hill 1999. ISBN: 0-07-034003-X Electronic ISBN: 1-59124-404-8

Nábrádi A.(2007): Quality in the pork verticum. Gazdálkodás, 51. évf. 3. sz. 32-50. p. HU ISSN 0046-5518

S. Shiba, A. Graham, D. Walden: (1993) A New American Tqm: Four Practical Revolutions in Management. Productivity Press Inc (1993) ISBN-10: 1563270323, ISBN-13: 978-1563270321

Szabó J. (2006): Az állati eredetű élelmiszerek biztonsága. Állattenyésztés és Takarmányozás. Különszám. Vol. 55. 2006. 15-34. p. 
